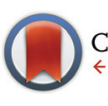

CrossMark \& click for updates

Cite this: Dalton Trans., 2015, 44 12700

Received 20th April 2015, Accepted 29th May 2015

DOI: $10.1039 / c 5 d t 01496 d$ www.rsc.org/dalton

\title{
Copper(II) complexes of macrocyclic and open-chain pseudopeptidic ligands: synthesis, characterization and interaction with dicarboxylates $\uparrow$
}

\author{
Enrico Faggi, ${ }^{* a}$ Raquel Gavara, ${ }^{\mathrm{b}}$ Michael Bolte, ${ }^{\mathrm{C}}$ Lluís Fajarí, ${ }^{a}$ Luís Juliá, \\ Laura Rodríguez ${ }^{b}$ and Ignacio Alfonso*a
}

\begin{abstract}
Mono- and dinuclear $\mathrm{CU}(॥)$ complexes were prepared with pseudopeptidic open chain and macrocyclic ligands, respectively. They were characterized by UV-vis spectroscopy, EPR, HRMS and X-ray diffraction. The $\mathrm{Cu}(\|)$ cation is coordinated by two amines and two deprotonated amides, in a slightly distorted square planar coordination geometry. The complexes interact with several substituted dicarboxylates, as shown by UV-vis titrations and EPR experiments. The interaction of both mono- and dinuclear complexes with very similar dicarboxylates of biological interest (malate and aspartate) resulted in strikingly different outcomes: in the first case a ternary complex [ligand...metal...dicarboxylate] was obtained almost quantitatively, while in the latter, the $\mathrm{Cu}(॥)$ displacement to form $\mathrm{Cu}(\mathrm{Asp})_{2}$ was predominant.
\end{abstract}

\section{Introduction}

The $\mathrm{Cu}$ (II) cation plays a key role in bioinorganic chemistry as it is present in many enzymes with a variety of essential functions. ${ }^{1,2}$ Copper enzymes usually contain metal ions bound to a specific amino acid residue or directly to the amide group carbonyl or nitrogen - in the peptide backbone, offering different coordination environments. ${ }^{3}$ For example, naturallyoccurring cyclic peptides form mono- and dinuclear $\mathrm{Cu}(\mathrm{II})$ complexes, with different coordination geometries. ${ }^{4} \mathrm{The} \mathrm{Cu}(\mathrm{II})$ ion also interacts with $\alpha$ synuclein ( $\alpha \mathrm{Syn})$, and fragments of Park9 encoded protein from the Parkinson's disease gene. ${ }^{5}$ Additionally, $\mathrm{Cu}(\mathrm{II})$ ionophores have been studied recently as potential therapeutic agents. ${ }^{6}$ Thus, an appropriate design of small molecules with suitable structural and functional characteristics could be important for biomimetic and recognition studies. In this regard, the design and synthesis of

\footnotetext{
${ }^{a}$ Departamento de Quimica Biológica y Modelización Molecular, IQAC-CSIC, Jordi Girona, 16-26, E-08034 Barcelona, Spain. E-mail: enrico.faggi@iqac.csic.es, ignacio.alfonso@iqac.csic.es

${ }^{b}$ Departament de Química Inorgànica, Universitat de Barcelona, Martí i Franquès 1-11, 08028 Barcelona, Spain

${ }^{c}$ Institut für Anorganische Chemie, J.-W.-Goethe-Universität, Max-von-Laue-Str.7, D-60438 Frankfurt/Main, Germany

$\dagger$ Electronic supplementary information (ESI) available: ${ }^{1} \mathrm{H}-\mathrm{NMR},{ }^{13} \mathrm{C}-\mathrm{NMR}$ spectra of the new ligands, HRMS spectra of the ligands and the complexes, UVvis and EPR spectra of the complexes and their adducts with dicarboxylates. CCDC 1059975 and 1059976. For ESI and crystallographic data in CIF or other electronic format see DOI: 10.1039/c5dt01496d
}

ligands functionalized to achieve metal complexation through a biomimetic approach is a challenge of current interest. The use of oligopeptides ${ }^{7}$ and simple ligands that contain amino acid residues ${ }^{8}$ is a successful strategy to provide the $\mathrm{Cu}(\mathrm{II})$ ions with a coordination environment similar to that found in metalloproteins.

In this context, (amino amide) compounds ${ }^{9}$ are promising ligands for several reasons: (i) they contain two kinds of nitrogen atoms, with different coordination capabilities, connected through a chiral backbone; (ii) their properties can be tuned by the variation of the substituents and the spacers and (iii) they can form stable metal complexes with transition metals. ${ }^{10}$ On the other hand, different bis(amino amides) have been used as building blocks for the construction of macrocyclic or macrobicyclic structures. Some of these systems display interesting features, acting as in vivo fluorescent $\mathrm{pH}$ probes, ${ }^{11}$ or as selective receptors for substrates of biological relevance. ${ }^{12}$

Recently, the coordination ability of some $C_{2}$ symmetrical bis(amino amides) derived from valine towards $\mathrm{Cu}$ (II) and $\mathrm{Zn}$ (II) ions has been reported ${ }^{13}$ and, for the same family of ligands, the effect of changes in the amino acidic residue towards the coordination of $\mathrm{Cu}(\mathrm{II})$ was evaluated. ${ }^{14}$ Here, we present a study of the $\mathrm{Cu}(\mathrm{II})$ binding ability of two open-chain and two macrocyclic (amino amide) ligands derived from phenylalanine. This particular amino acid was selected because some phenylalanine-derived receptors have been shown to be better hosts for cations than those obtained from valine.$^{15}$ In view of the multiple and important roles played by dicarboxylate anions in living systems, ${ }^{16}$ we also studied the 
interaction of the obtained $\mathrm{Cu}$ (II) complexes with a series of dicarboxylates with similar structures and of high biological interest, such as malate and aspartate.

\section{Results and discussion}

\section{Synthesis and characterization of the ligands}

For this study we selected four ligands (L1-L4) with closely related structures. Thus, L1 and $\mathbf{L} 2$ are open-chain bis(amino amide) receptors that differ slightly in the length of the aliphatic spacer connecting the amide nitrogens. In principle, they are designed to coordinate $\mathrm{Cu}(\mathrm{II})$ forming mononuclear complexes. On the other hand, $\mathbf{L 3}$ and $\mathbf{L} \mathbf{4}$ are tetra(amino amide) macrocyclic ligands with different geometries of the aromatic spacer that connect the amine nitrogens. They are designed to coordinate $\mathrm{Cu}(\mathrm{II})$ forming dinuclear complexes. Overall, the complexes derived from these ligands allowed: (i) comparison of mononuclear and dinuclear $\mathrm{Cu}$ (II) complexes, determining which molecular architecture was more efficient in the further coordination of dicarboxylates and (ii) an evaluation of the possible effect of the length of the spacer.

The general structure and synthetic pathways of the considered ligands are displayed in Scheme 1. Primary diamines 1 and 2 , derived from phenylalanine, are easily prepared starting from the corresponding $N-\mathrm{Cbz}$ protected phenylalanine $N$-hydroxysuccinimidyl ester, coupled with either 1,2-diaminoethane or 1,3-diaminopropane and final $\mathrm{N}$-deprotection following previously reported procedures. ${ }^{17}$ Diamines $\mathbf{1}$ and 2 were subjected to a reductive amination process with benzaldehyde in methanol, affording the new ligands $\mathbf{L} 1$ and $\mathbf{L} 2$ in good yields. On the other hand, macrocyclic ligands L3 and L4 were obtained by reaction of diamine 1 with either terephth-

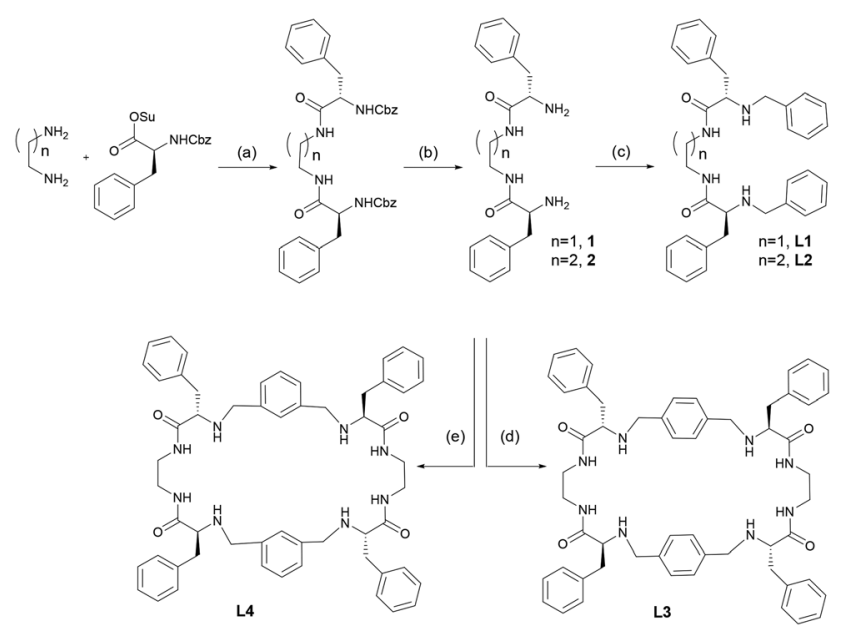

Scheme 1 Synthetic route and structure of L1-L4 ligands. (a) Tetrahydrofuran, 20 h, r.t., $70-90 \%$ (b) $\mathrm{HBr} / \mathrm{AcOH}, 1$ h, r.t., $70-80 \%$; (c) (i) benzaldehyde, methanol, 20 h, r.t. (ii) sodium borohydride, 20 h, r.t., 44-81\%; (d) (i) terephthaldehyde, (TBA) ${ }_{2}$-terephthalate, methanol, $24 \mathrm{~h}$, r.t. (ii) sodium borohydride, 24 h, r.t., $65 \%$; (e) isophthaldehyde, (TBA) $2^{-}$ isophthalate, methanol, $24 \mathrm{~h}$, r.t. (ii) sodium borohydride, $24 \mathrm{~h}$, r.t., $30 \%$.
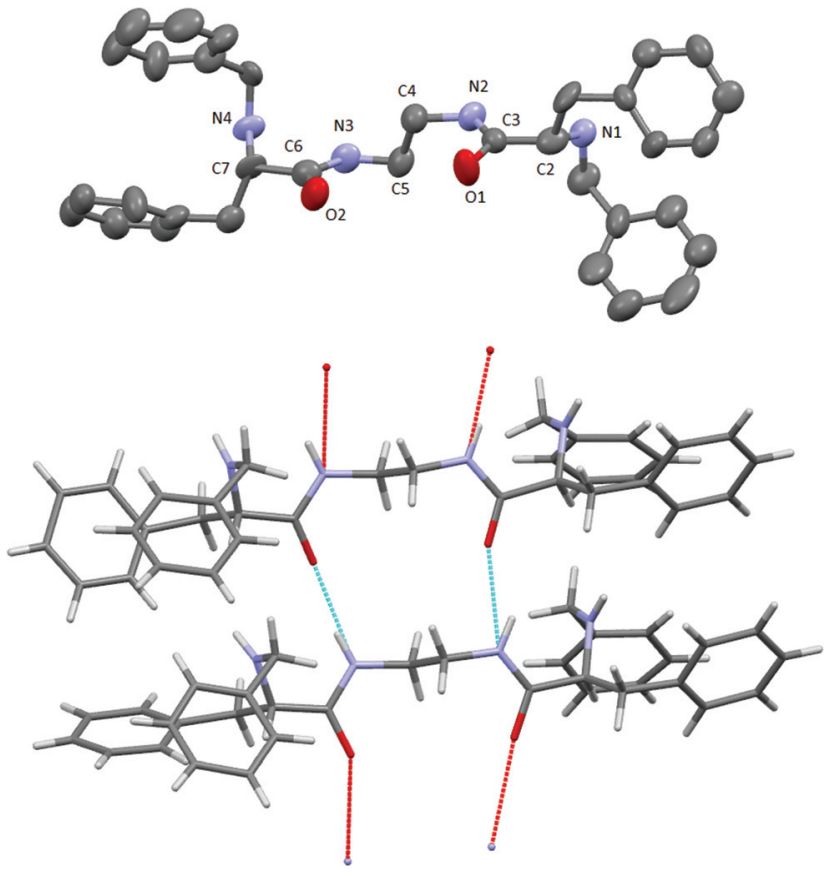

Fig. 1 X-ray crystal structure of ligand L1. Hydrogens are omitted for clarity (top). Asymmetric unit of ligand L1 (bottom). Carbon (grey), oxygen (red), nitrogen (blue), hydrogen bond (pale blue).

aldehyde or isophthaldehyde in the presence of a suitable template agent (tetrabutylammonium terephthalate or isophthalate, respectively), in a macrocyclization reaction that has already been described. ${ }^{18}$

The new ligands $\mathbf{L} 1$ and $\mathbf{L} 2$ were characterised using standard techniques $\left({ }^{1} \mathrm{H}-\mathrm{NMR},{ }^{13} \mathrm{C}-\mathrm{NMR}, \mathrm{HRMS}\right)$ and in the case of L1, crystals suitable for single-crystal X-ray diffraction analysis were obtained. A rather concentrated solution of L1 in methanol was left evaporating slowly at room temperature. After four days, colourless elongated crystals of good quality were obtained.

The results of the X-ray diffraction of the crystal structure are shown in Fig. 1 (top) together with the corresponding asymmetric unit (Fig. 1, bottom). The asymmetric unit contains two independent molecules that are linked by two hydrogen bonds. These H-bonds induce a global parallel disposition of the molecules (Fig. S23†). Selected bond distances and angles are summarized in Table S2. $\dagger$ Carbonyl groups from amides are located in the syn position, pointing to the same direction, due to the establishment of hydrogen bonds with neighbouring molecules (Fig. 1 bottom).

\section{Synthesis and characterization of the copper(II) complexes}

The copper(II) complexes of both open-chain and macrocyclic ligands were prepared by applying slight modifications to a previously reported procedure. ${ }^{14}$ Bis(amino amide) ligands $\mathbf{L 1}$ and $\mathbf{L} 2$ were reacted with one equivalent of $\mathrm{CuSO}_{4}$ in methanol, in the presence of two equivalents of $\mathrm{NaOH}$, to ensure the 

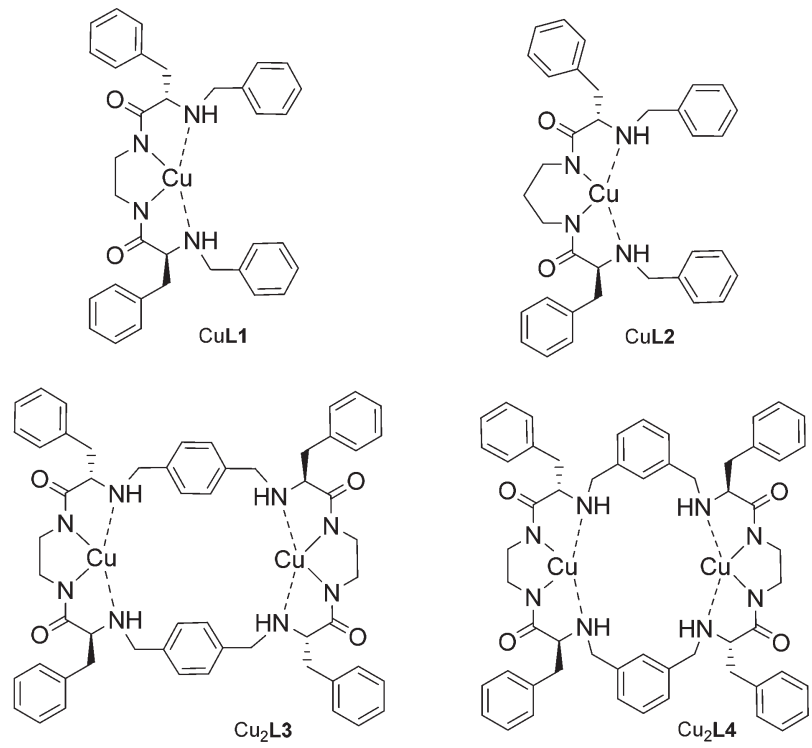

Scheme 2 Structures of the four Cu(II) complexes.

Table 1 Absorption maxima $\left(\lambda_{\max }\right)$ and molar absorptivity $(\varepsilon)$ of the corresponding $\mathrm{Cu}(\mathrm{II})$ complexes of L1-L4 in methanol

\begin{tabular}{lll}
\hline Complex & $\lambda_{\max }(\mathrm{nm})$ & $\varepsilon\left(\mathrm{M}^{-1} \mathrm{~cm}^{-1}\right)$ \\
\hline CuL1 & 510 & 226 \\
$\mathrm{CuL2}$ & 498 & $150^{a}$ \\
$\mathrm{Cu}_{2} \mathbf{L} 3$ & 526 & 365 \\
$\mathrm{Cu}_{2} \mathbf{L 4}$ & 519 & 319
\end{tabular}

${ }^{a}$ Value obtained at the lowest studied concentration $\left(1 \times 10^{-4} \mathrm{M}\right)$ since hyperchromicity was observed upon dilution.

complete deprotonation of the ligand amide groups. Bright purple solutions were obtained, while a white solid was discarded. Solutions were concentrated to afford the mononuclear complexes CuL1 and CuL2 as purple solids. Similarly, tetra(amino amide) ligands $\mathbf{L} 3$ and $\mathbf{L} \mathbf{4}$ were reacted with two equivalents of $\mathrm{CuSO}_{4}$ and four equivalents of $\mathrm{NaOH}$, affording dinuclear complexes $\mathrm{Cu}_{2} \mathbf{L} \mathbf{3}$ and $\mathrm{Cu}_{2} \mathbf{L} \mathbf{4}$. The structures of the four complexes are displayed in Scheme 2.

All complexes were characterized by means of high resolution mass spectrometry, affording in all cases the expected molecular peaks with the correct isotopic patterns (Fig. S9S12†).

In the UV-vis spectra, all complexes exhibit intense ligand to metal charge transfer transitions (LMCT) in the range of 200-315 nm (Fig. S13†). A less intense absorption band, responsible for the purple-violet colour and due to $\mathrm{d}-\mathrm{d}$ transitions, is present in the range $498-526 \mathrm{~nm}$, suggesting $\mathrm{Cu}(\mathrm{II})$ coordination geometries ranging from square-planar to square-pyramidal. ${ }^{13}$ Table 1 collects the wavelength of maximum absorbance for the $\mathrm{d}-\mathrm{d}$ transitions $\left(\lambda_{\max }\right)$ of all complexes together with the corresponding molar absorptivity $(\varepsilon)$.

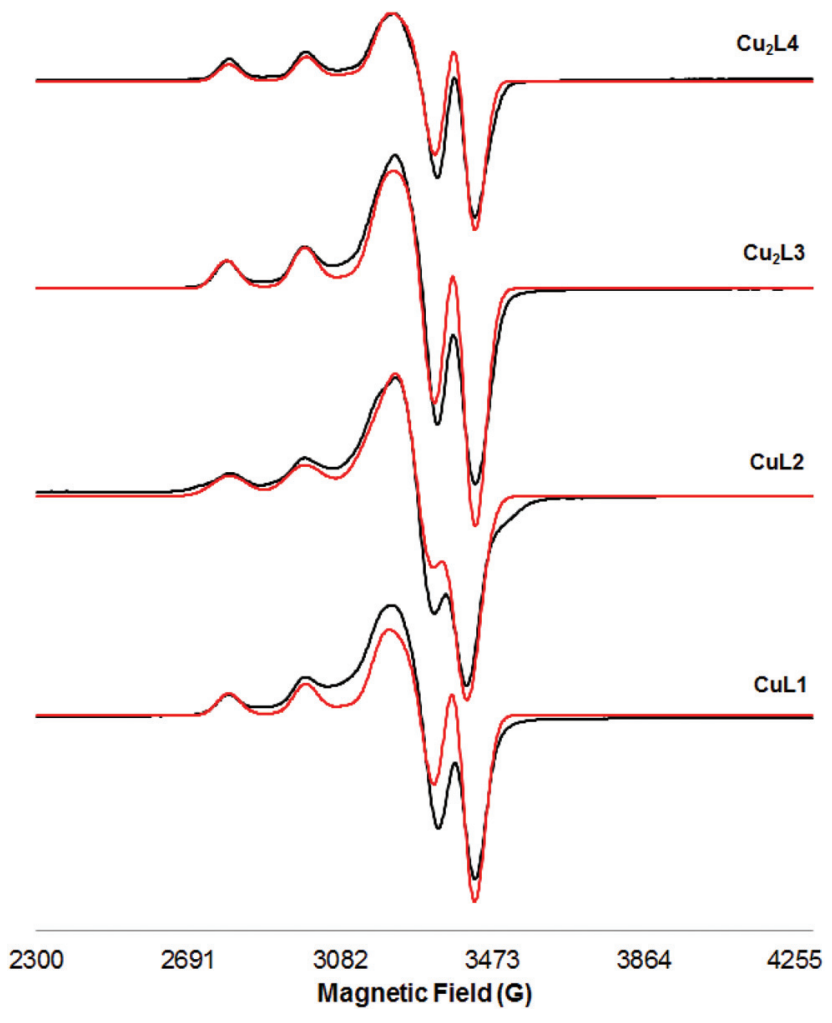

Fig. 2 X-band EPR spectra of a frozen methanol solution (103 K) of $\mathrm{Cu}(I)$ complexes (black: experimental; red: simulated).

The $\varepsilon$ value of $\mathbf{C u L 2}$ is concentration-dependent, as further confirmed by a dilution study (Fig. S70 $\dagger$ ), indicating that this complex undergoes self-aggregation in methanol. This unique feature of $\mathbf{C u L 2}$ complicated the study of its binding properties by UV-vis spectroscopy.

Besides, upon the $\mathrm{Cu}(\mathrm{II})$ complex formation, the IR band corresponding to the stretching of the carbonyl amide of the ligands suffers a shift $\left(54-63 \mathrm{~cm}^{-1}\right)$ to lower wavenumbers (Fig. S18-S21†). This indicates the participation of the deprotonated amide groups in the coordination to $\mathrm{Cu}(\mathrm{II})$, in agreement with the data obtained by EPR and the X-ray diffraction of the crystal structure of CuL2 (see below).

The X-band EPR spectrum of a frozen methanol solution at $103 \mathrm{~K}$ of $\mathrm{Cu}(\mathrm{II})$ complexes is shown in Fig. 2. The Hamiltonian parameters obtained from the simulated spectra of these compounds are summarized in Table 2 (entries 1-4).

The simulated parameters show excellent agreement with the experimental spectra. All the spectra show a characteristic axial symmetry $\left(g_{\|}>g_{\perp}>g_{\mathrm{e}}=2.0023\right)$, and indicate that the copper ions have a square planar coordination. In all cases $g_{\|}$ and $A_{\|}$parameters are typical of neutral $\mathrm{CuN}_{4}$ units according to the Peisach and Blumberg plot ${ }^{19}$ (Fig. S32 $\dagger$ ), pointing out that the metal centres are equatorially coordinated by four nitrogen atoms (two amines and two deprotonated amides). The values of the $g_{\|} / A_{\|}$ratio can be used as a convenient empirical index of tetrahedral distortion in $\mathrm{Cu}(\mathrm{II})$ complexes; ${ }^{20}$ 
Table 2 Best fit EPR spectroscopic parameters of $\mathrm{Cu}$ complexes in solid solution $(\mathrm{MeOH}, 103 \mathrm{~K})$

\begin{tabular}{|c|c|c|c|c|c|c|c|c|}
\hline Entry & Complex & $A_{\|}{ }^{a}$ & $A_{\perp}^{a}$ & $A_{\mathrm{N}}{ }^{a}$ & $g_{\|}$ & $g_{\perp}$ & $g_{\|} / A_{\|}^{b}$ & Type \\
\hline 1 & CuL1 & 199.5 & 23.6 & 14.7 & 2.1822 & 2.0413 & 107.4 & $\mathrm{CuN}_{4}$ \\
\hline 2 & $\mathrm{CuL2}$ & 200.8 & 21.0 & 15.7 & 2.1852 & 2.0414 & 108.8 & $\mathrm{CuN}_{4}$ \\
\hline 4 & $\mathrm{Cu}_{2} \mathbf{L 4}$ & 197.5 & 24.8 & 14.7 & 2.1846 & 2.0405 & 108.5 & $\mathrm{CuN}_{4}$ \\
\hline 5 & $\mathrm{Cu}_{2} \mathbf{L} \mathbf{3}+\mathrm{Suc}$ & 191.4 & 23.2 & 14.8 & 2.1862 & 2.0486 & 111.9 & $\mathrm{CuN}_{4}$ \\
\hline 6 & $\mathrm{Cu}_{2} \mathbf{L} \mathbf{3}+\mathrm{Mal}$ & 162.8 & 25.6 & 12.8 & 2.2422 & 2.0487 & 131.6 & $\mathrm{CuN}_{2} \mathrm{O}_{2}$ \\
\hline 7 & $\mathrm{Cu}_{2} \mathbf{L} \mathbf{3}+\mathrm{Asp}$ & 168.2 & 17.6 & 12.3 & 2.2609 & 2.0492 & 127.4 & $\mathrm{CuN}_{2} \mathrm{O}_{2}$ \\
\hline 10 & $\mathrm{Cu}(\mathrm{Asp})_{2}$ & 167.5 & 17.6 & 11.3 & 2.2611 & 2.0463 & 127.9 & $\mathrm{CuN}_{2} \mathrm{O}_{2}$ \\
\hline
\end{tabular}

${ }^{a}$ Values of coupling constants in gauss. ${ }^{b}$ Value of $A_{\|}$in $\mathrm{cm}^{-1} \cdot A\left[\mathrm{~cm}^{-1}\right]=0.46686 \times 10^{-4} \mathrm{~g} A[\mathrm{G}] .{ }^{c}$ A minor component is also detected (see Table S3).

in the studied cases, values of $g_{\|} / A_{\|}$fall within the $105-135 \mathrm{~cm}$ range, typical of $\mathrm{Cu}$ (II) complexes possessing a non-distorted square-planar structure with a $\mathrm{d}_{x^{2}-y^{2}}$ ground state. Finally, the large similarity between EPR spectra of mononuclear and dinuclear complexes, and the absence of a half-field signal at around $1600 \mathrm{G}$ due to the $\Delta_{\mathrm{ms}}= \pm 2$ transition in both frozen methanol $(107 \mathrm{~K})$ and DMF $(103 \mathrm{~K})$ solutions (Fig. S27 and $\left.\mathrm{S} 28^{\dagger}\right)$ rule out any $\mathrm{Cu}-\mathrm{Cu}$ dipolar interaction; i.e., dinuclear $\mathrm{Cu}$ (II) complexes $\mathrm{Cu}_{2} \mathbf{L} \mathbf{3}$ and $\mathrm{Cu}_{2} \mathbf{L} \mathbf{4}$ behave as mononuclear complexes. This is also confirmed by the absence of the specific bands of the triplet state in the spectrum of the $\mathrm{Cu}_{2} \mathbf{L} \mathbf{3}$ complex in the solid state $(103 \mathrm{~K}$, field scan range: 0 to $7000 \mathrm{G}$, Fig. S29†).

Crystals suitable for single-crystal X-ray diffraction analysis were obtained in the case of CuL2. A solution of CuL2 in methanol was left evaporating slowly at room temperature; after two days, square purple crystals of good quality were obtained.

The X-ray crystal structure is presented in Fig. 3 and selected bond distances and angles are presented in Table S2. $\dagger$

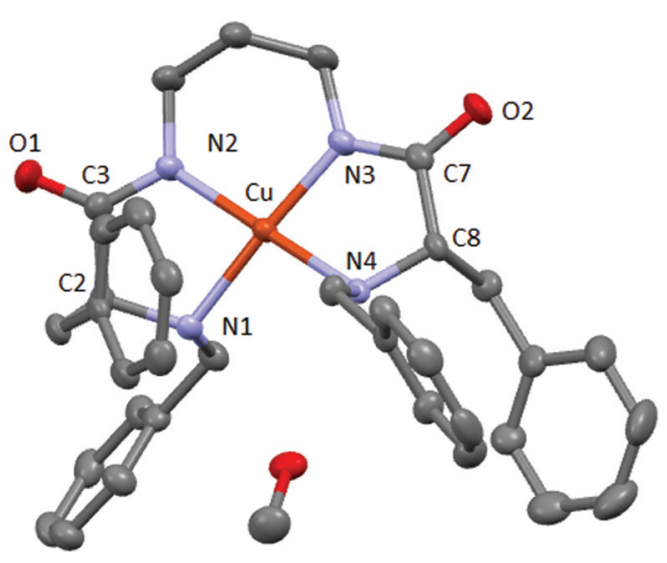

Fig. 3 X-ray crystal structure of CuL2. Carbon (grey), oxygen (red), nitrogen (blue) and copper (orange).
X-ray diffraction data confirm the formation of the copper complex with a $1: 1$ stoichiometry. The complex crystallizes with one molecule of methanol that establishes hydrogen bonds with one amine group of the same molecule and with the amide carbonyl group of another molecule (Fig. S24†). The copper(II) cation is coordinated by two amine groups and two deprotonated amide groups, in a slightly distorted square planar geometry, and displays a torsion angle of $11.84^{\circ}$ (between the plane containing $\mathrm{N} 4-\mathrm{Cu}-\mathrm{N} 3$ and that containing N3-Cu-N2, see Fig. S25†).

The $\mathrm{Cu}-\mathrm{N}_{\text {amide }}$ distances are slightly shorter than the corresponding $\mathrm{Cu}-\mathrm{N}_{\text {amine }}$ being 1.919 and $2.043 \AA$ on average, respectively. This fact was previously observed for analogous $\mathrm{Cu}$-pseudopeptidic complexes and was attributed to the anionic coordination from the deprotonated $\mathrm{N}_{\text {amide }}$ donors instead of the neutral donation from the $\mathrm{N}_{\text {amine }}$ groups. ${ }^{14}$ The $\mathrm{N}-\mathrm{Cu}-\mathrm{N}$ angles contained in the five membered rings $(\mathrm{N} 1-\mathrm{Cu}-$ $\mathrm{N} 2$ and $\mathrm{N} 3-\mathrm{Cu}-\mathrm{N} 4)$ are $c a .10^{\circ}$ smaller than the others (N2$\mathrm{Cu}-\mathrm{N} 3$ and $\mathrm{N} 1-\mathrm{Cu}-\mathrm{N} 4)$, as expected for a smaller ring size with a tighter environment. These values are slightly shorter than those obtained for an analogous copper complex with a three methylene chain spacer between the amide groups. The corresponding $\mathrm{N} 1-\mathrm{Cu}-\mathrm{N} 3$ and $\mathrm{N} 2-\mathrm{Cu}-\mathrm{N} 4$ distances are shorter than linear symmetry and also slightly shorter than in a previous analogous copper complex. ${ }^{14}$

Unfortunately, we were not able to obtain suitable crystals for X-ray diffraction with the $\mathrm{Cu}(\mathrm{II})$ complexes of the other ligands. However, the very similar UV-vis and EPR spectroscopic data support that the coordination environment of the copper ion is virtually identical for all the complexes.

\section{Interaction of the copper complexes with dicarboxylates}

Many short-chain dicarboxylates play a role in biotransformations. For example, succinate (Suc) acts as an electron donor in the citric acid cycle and plays a crucial role in adenosine triphosphate (ATP) generation in mitochondria. ${ }^{21}$ Malate (Mal) also takes part in the citric acid cycle and is a source of $\mathrm{CO}_{2}$ in the Calvin cycle. ${ }^{22}$ Aspartate (Asp) is the precursor to several amino acids, including four that are essential for humans: 
methionine, threonine, isoleucine, and lysine $;^{23}$ it is also an important neurotransmitter. ${ }^{24}$

Among others, ${ }^{25}$ a variety of receptors and sensors for dicarboxylates containing two $\mathrm{Cu}$ (II) centres have been reported due to the bidentate nature of these anions and the good affinity of the carboxylate group for the $\mathrm{Cu}(\mathrm{II})$ ion. ${ }^{26}$ Most of the reported systems are dicopper complexes of polyamine macrocycles ${ }^{27}$ and cryptands. ${ }^{28}$ In this study we investigate the coordination properties of $\mathrm{Cu}$ (II) complexes coordinated by both amine and amide nitrogens present in pseudopeptidic ligands, in an environment that resembles more closely a metalloprotein.

We started our study with $\mathrm{Cu}_{2} \mathbf{L} \mathbf{3}$, as we reasoned that the presence of two $\mathrm{Cu}$ (II) ions at a close distance in its structure would make this complex a good receptor for short-chain dicarboxylate anions. We carried out an initial screening of various dicarboxylates (aliphatic dicarboxylic acids, amino acids and hydroxy acids) as potential guests for the complex by comparing the absorbance of the CuL3 complex alone and in the presence of 2 equivalents of dicarboxylate. Interestingly, in most cases the absorption spectrum was not affected by the addition of the dicarboxylate, while in a few cases the initial purple solution turned light blue or light green. We then focused on some particular cases and studied them in depth, by accurate UV-vis titration experiments in methanol. Unfortunately, solubility issues of the metal complexes prevented us from performing this study in water. Also, all the dicarboxylate substrates were used as the corresponding bis(tetrabutylammonium) (TBA) salts for a better solubility in methanol.

The most striking cases were those of Mal, Asp and Glu (throughout the study, the naturally occurring $\mathrm{L}$ isomers were always used). Titration of $\mathrm{Cu}_{2} \mathbf{L} 3$ with Mal showed a bathochromic shift in $\lambda_{\max }$ from 526 to $575 \mathrm{~nm}$ (Fig. 4, top right) resulting in a change in colour from intense purple to light green. A similar trend from purple to pale blue was observed in the case of the of the corresponding TBA salts of Asp and Glu: the $\lambda_{\text {max }}$ shifted to $628 \mathrm{~nm}$ (Fig. 4, top left) and $604 \mathrm{~nm}$, respectively. In contrast, addition of succinate had no effect on the absorption spectrum of the system (Fig. S34†). The case of $\mathrm{N}$-acetyl-L-aspartate ( $\mathrm{N}$-Ac-Asp) was intermediate: the intensity of the absorption band at $526 \mathrm{~nm}$ decreased, but only to a low extent $(\approx 20 \%$ of the initial value). A general trend clearly emerged from these titrations: complex $\mathrm{Cu}_{2} \mathbf{L} \mathbf{3}$ was able to coordinate dicarboxylates with a heteroatom in the $\alpha$ position to one $\mathrm{COO}^{-}$group. However, the dicarboxylates having the protected heteroatom were weakly coordinated and those lacking the heteroatom were not coordinated at all.

Following this, the titration curves of malate and aspartate were analysed more in-depth. Job plots were built by reporting $\Delta_{\mathrm{Abs}} / \chi_{\text {anion }}$ as a function of $\chi$ anion (calculated with respect to $\mathrm{Cu})$. In the case of malate, the plot shows a maximum for $\chi_{\text {anion }}=0.50$ (Fig. S38†) thus indicating that the $\mathrm{Cu}$ : Mal ratio in the formed species is $1: 1$. Accordingly, this result implies the binding of two equivalents of Mal per $\mathrm{Cu}_{2} \mathbf{L} 3$ complex molecule. Moreover, comparison of the absorption spectrum of $\mathrm{Cu}(\mathrm{Mal})_{2}$ (obtained by addition of 2.0 equivalents of Mal to a solution of $\mathrm{CuSO}_{4}$ ), with that obtained after the addition of
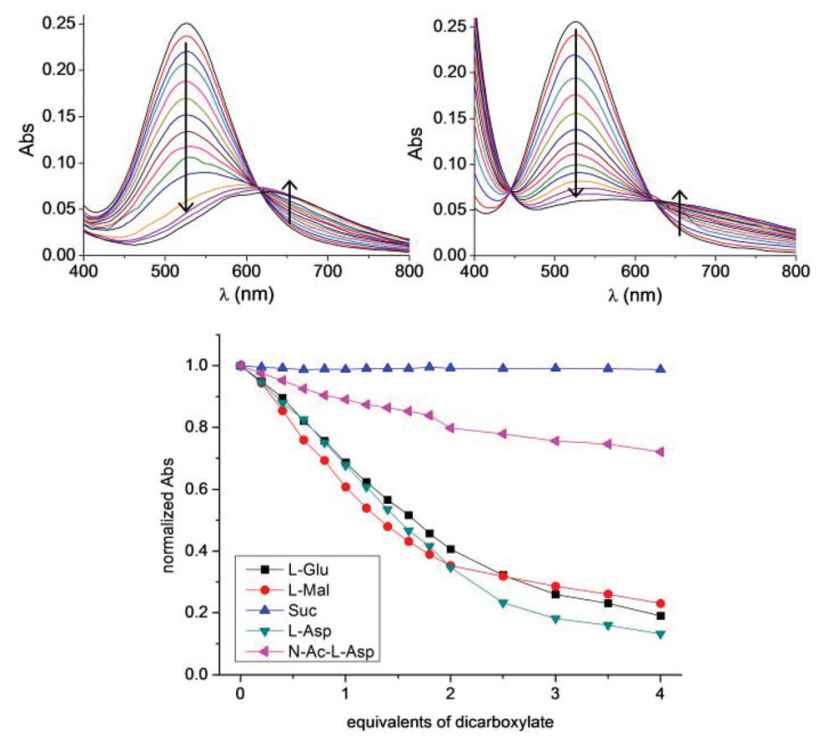

Fig. 4 UV-vis absorption spectra of $\mathrm{Cu}_{2} \mathrm{~L} 3\left(1 \times 10^{-3} \mathrm{M}\right.$, methanol) in the absence and in the presence of increasing amounts of bis(TBA) salts of Asp, (top, left) and Mal, (top, right); changes in the normalized absorbance at $525 \mathrm{~nm}$ of $\mathrm{Cu}_{2} \mathrm{~L} 3$ upon addition of dicarboxylates (bottom; blue: Suc; pink: $N$-Ac-Asp; black: Glu; green: Asp; red: Mal).

the deprotonated L3 ligand rendered two significantly different spectra. The first has a $\lambda_{\max }=691 \mathrm{~nm}\left(\varepsilon=43 \mathrm{M}^{-1}\right.$ $\left.\mathrm{cm}^{-1}\right)$ while the second has a $\lambda_{\max }=649 \mathrm{~nm}\left(\varepsilon=41 \mathrm{M}^{-1} \mathrm{~cm}^{-1}\right)$ (Fig. S39†). These combined data are consistent with the formation of a ternary complex with the formula $\mathrm{Cu}_{2} \mathbf{L} 3 \mathrm{Mal}_{2}$.

The case of aspartate is different: the Job plot shows a maximum for $\chi_{\text {anion }}=0.56$ (Fig. S44 $\dagger$ ). This value is intermediate between 0.5 and 0.66 , suggesting the simultaneous presence of different species, with $\mathrm{Cu}$ : Asp ratios of $1: 1$ and $1: 2 .+$ The comparison of the absorption spectrum of $\mathrm{CuAsp}_{2}$ (obtained by addition of 2.0 equivalents of Asp to a solution of $\mathrm{CuSO}_{4}$ ), with that obtained after the addition of the deprotonated $\mathbf{L 3}$ ligand returned two almost identical spectra: the first has $\lambda_{\max }=634 \mathrm{~nm}\left(\varepsilon=47 \mathrm{M}^{-1} \mathrm{~cm}^{-1}\right)$ while the second has $\lambda_{\max }$ $=635 \mathrm{~nm}\left(\varepsilon=49 \mathrm{M}^{-1} \mathrm{~cm}^{-1}\right)$ (Fig. S45†). These combined data suggest the presence of both $\mathrm{Cu}_{2} \mathbf{L} 3 \mathrm{Asp}_{2}$ and $\mathrm{CuAsp} \mathrm{s}_{2}$ species, the latter being predominant. In other words, aspartate is able to displace a high fraction of the $\mathrm{Cu}$ (II) ion from the macrocyclic ligand $\mathbf{L}$.

These conclusions are supported by the EPR studies. Addition of Suc did not affect the EPR spectrum of the $\mathrm{Cu}_{2} \mathbf{L 3}$ complex, while addition of a small excess (ca. 3 eq.) of Mal and Asp altered it (Table 2, entries 3, 5-7 and Fig. 5). The value of $A_{\|}$decreased from $190.4 \mathrm{G}$ to $162.8 \mathrm{G}$ (Mal) and 168.2 G (Asp) while that of $g_{\|}$increased from 2.1884 to 2.2422 (Mal) and 2.2609 (Asp). These changes of the EPR parameters imply a modification of the coordination environment of the metal

$\$$ Analysis of the titration data with Glu rendered the same result (Job plot maximum for $\left.\chi_{\text {anion }}=0.60\right)$. 


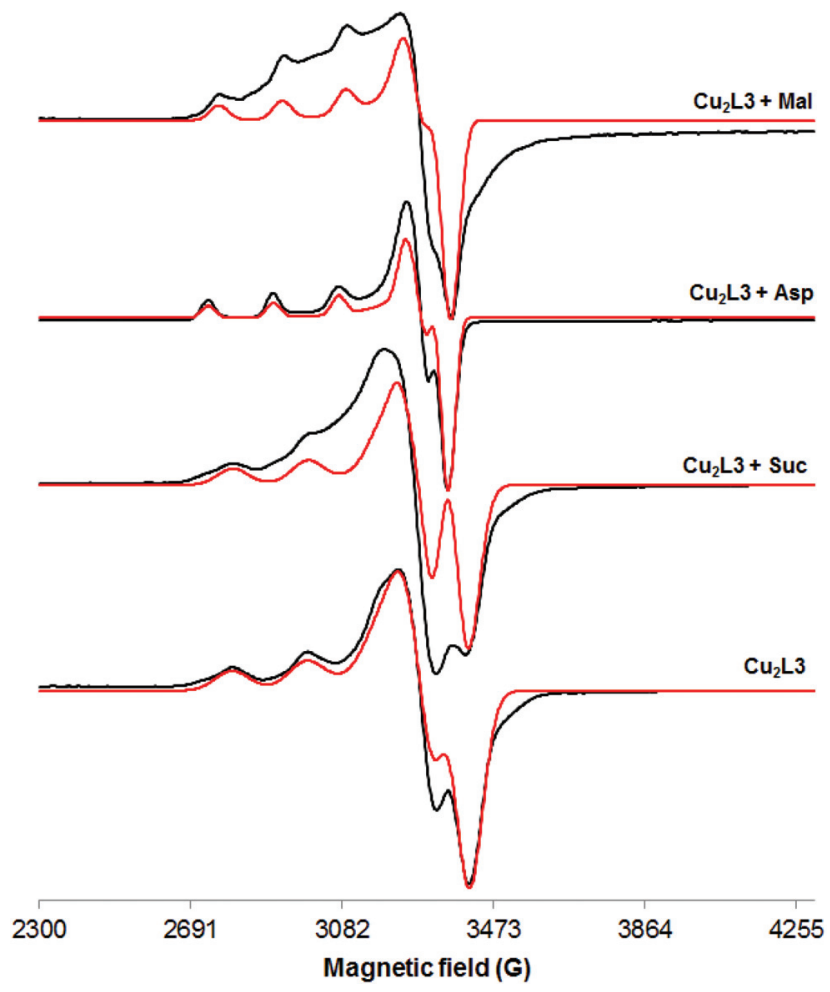

Fig. 5 X-band EPR spectra of a frozen methanol solution (103 K) of $\mathrm{Cu}_{2} \mathrm{~L} 3$ alone and in the presence of different dicarboxylate anions (black: experimental; red: simulated).

centre from $\mathrm{CuN}_{4}$ to $\mathrm{CuN}_{2} \mathrm{O}_{2}$, maintaining the overall neutral charge (Fig. S33†). Since Mal has no nitrogen atoms in its structure, this result suggests that Mal coordinates to $\mathrm{Cu}(\mathrm{II})$ through its alcohol and carboxylate groups, displacing one (amino amide) moiety of L3. On the other hand, the amino acids, Asp and Glu, can coordinate the $\mathrm{Cu}(\mathrm{II})$ ion via the carboxylate and the amine groups, thus displacing L3 almost completely.

Due to the paramagnetic nature of the $\mathrm{Cu}(\mathrm{II})$ ion, its complexes are usually difficult to study by means of NMR spectroscopy, as their spectra show severe broadening of the signals. ${ }^{29}$ However, we undertook a ${ }^{1} \mathrm{H}$-NMR study of $\mathrm{Cu}_{2} \mathbf{L} 3$ and its Asp and Mal adducts. All the signals in the ${ }^{1} \mathrm{H}-\mathrm{NMR}$ spectrum of $\mathrm{Cu}_{2} \mathbf{L} 3$ (Fig. S71, $\uparrow$ bottom) were broad and poorly resolved, suggesting a close connection of the organic ligand with the $\mathrm{Cu}(\mathrm{II})$ ion. Upon the addition of 2.0 equivalents of Asp, some very broad signals of $\mathbf{L} \mathbf{3}$ sharpened (doublets at 3.60 and $3.30 \mathrm{ppm}$, doublets of doublets at 2.75 and $2.95 \mathrm{ppm}$ Fig. S71, $\uparrow$ top). Addition of 2.0 equivalents of Mal (Fig. S71, $\dagger$ middle) provoked a similar transformation on the signals of L3, but to a lesser extent. This different behaviour supports the observation that Mal has a minor tendency to displace $\mathrm{Cu}$ (II) ions from $\mathbf{L} 3$, as it mainly forms the ternary species $\mathrm{Cu}_{2} \mathbf{L} 3 \mathrm{Mal}_{2}$.

Ligand $\mathbf{L 4}$ is a macrocyclic structure that slightly differs from L3, due to the meta instead of the para substitution of the aromatic spacer. In principle, $\mathbf{L} 4$ would set the $\mathrm{Cu}(\mathrm{II})$ ions at a closer distance. To find out if this small variation had an effect on the interaction with dicarboxylates, we investigated the coordination properties of the $\mathrm{Cu}_{2} \mathbf{L} \mathbf{4}$ complex. However, both EPR and UV-vis spectra showed no substantial differences.

Although less studied, mononuclear Cu(II) complexes have also been employed in dicarboxylate binding. ${ }^{30}$ For this reason, and to gain further insight into the binding characteristics of the complexes, the coordination abilities of the openchain mononuclear analogue of $\mathrm{Cu}_{2} \mathbf{L} 3$, CuL1, were studied.

According to UV-vis titrations, the coordination properties of CuL1 towards Suc, Mal and Asp are very similar to those of $\mathrm{Cu}_{2} \mathbf{L} \mathbf{3}$, apart from the differences in the stoichiometry of the binding.

Titration of CuL1 with Mal showed a bathochromic shift in $\lambda_{\max }$ from 508 to $646 \mathrm{~nm}$, resulting in a change in color from intense purple to light green (Fig. S56†). In the case of Asp, it changed to light blue and the $\lambda_{\max }$ shifted to $631 \mathrm{~nm}$ (Fig. S61†). In contrast, addition of succinate had no effect on the absorption spectrum of the system (Fig. S54†). However, the titration curves for Mal and Asp (Fig. 6) are different; the first one is much steeper and reaches a plateau for 1.25 equivalents of Mal, while the latter one shows that saturation, if reached, requires a larger number of equivalents. The difference between Mal and Asp titration curves is clearer from the respective Job plots (inset in Fig. 6). Job plots were built by reporting $\Delta_{\mathrm{Abs}} / \chi_{\text {anion }}$ as a function of $\chi_{\text {anion. }}$. In the case of Mal, the plot shows a maximum for $\chi_{\text {anion }}=0.50$ thus indicating that the $\mathrm{Cu}$ : Mal ratio in the formed species is $1: 1$ (Fig. S58 We also compared the absorption spectrum of $\mathrm{CuMal}_{2}$ obtained by addition of 2.0 equivalents of Mal to a solution of $\mathrm{CuSO}_{4}$ in methanol, with that obtained after the addition of one equivalent of the deprotonated $\mathbf{L} 1$ ligand. The two spectra are different: the first has $\lambda_{\max }=697 \mathrm{~nm}$ while the second has

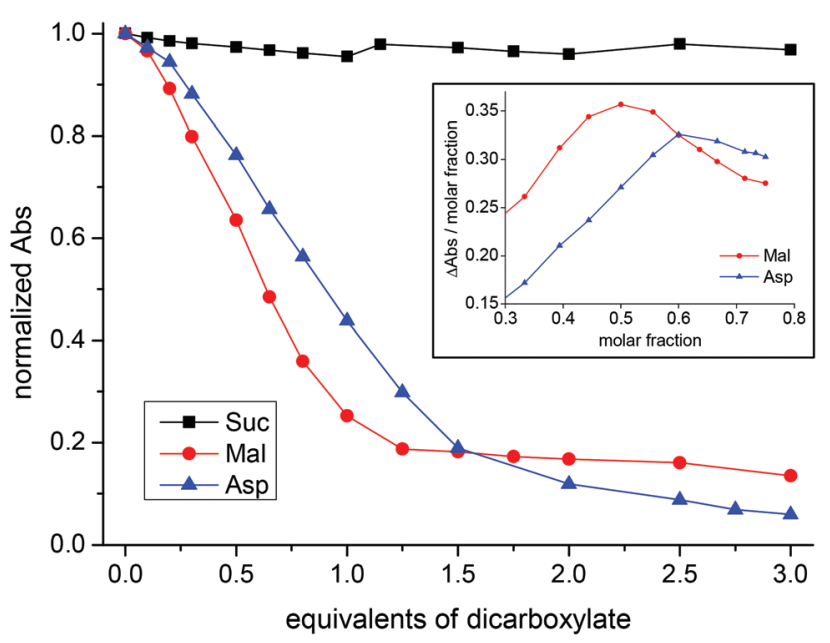

Fig. 6 Changes in the normalized absorbance at $508 \mathrm{~nm}$ of CuL1 upon addition of dicarboxylates (black: Suc; blue: Asp; red: Mal). Inset: Job plots for CuL1 + Asp (blue) and CuL1 + Mal (red). 
$\lambda_{\max }=666 \mathrm{~nm}$ (Fig. S59†). These combined data suggest the formation of a ternary complex with the formula CuL1Mal as the predominant species.

The case of Asp is quite different: the Job plot shows a maximum for $\chi_{\text {anion }}=0.60$ and the comparison of the absorption spectrum of $\mathrm{CuAsp}_{2}$ with that obtained after the addition of one equivalent of the deprotonated $\mathbf{L 1}$ ligand rendered two almost identical spectra (Fig. S63-S64†). Similarly to its macrocyclic analogue, the combined UV-vis data suggest the co-existence of a ternary complex (CuL1Asp) together with the CuAsp 2 complex. However, the percentage of $\mathrm{CuAsp}_{2}$ in this case should be higher (the Job plot maximum now is 0.60 ; for $\mathrm{Cu}_{2} \mathbf{L} 3$ it was 0.56). Not surprisingly, it would be easier for Asp to displace the $\mathrm{Cu}$ (II) ion from the open-chain ligand $\mathbf{L} 1$ than from the macrocyclic ligand $\mathbf{L} 3$.

The ${ }^{1} \mathrm{H}-\mathrm{NMR}$ study of CuL1 and its aspartate and malate adducts rendered similar results to those found for its macrocyclic counterpart $\mathrm{Cu}_{2} \mathbf{L} 3$ (Fig. S72 $\dagger$ ). The different aspect of the spectra supports the hypothesis that Mal forms mainly the ternary species CuL1Mal, while Asp has a higher tendency to displace $\mathrm{Cu}(\mathrm{II})$ ions from the pseudopeptidic ligand, leading mainly to the formation of the CuAsp 2 complex, together with a small amount of CuL1Asp ternary species.

\section{Detailed analysis of the interaction of CuL1 with Asp and Mal}

In view of the intricacy of the different equilibria taking place between the studied $\mathrm{Cu}(\mathrm{II})$ complexes and dicarboxylate anions, we undertook a detailed and quantitative study of the interaction between the simple mononuclear CuL1 complex and the Asp/Mal pair. First of all, we determined the binding constants and the stoichiometry of binding of Asp and Mal anions to the $\mathrm{Cu}$ (II) cation under our experimental conditions. In fact, amino acids and hydroxy acids are known to form stable complexes with $\mathrm{Cu}(\mathrm{II}),{ }^{31}$ with a $\mathrm{CuL}_{2}$ general formula. A solution of $\mathrm{CuSO}_{4}$ in methanol was titrated with Asp or Mal. The UV-vis spectral variations regarding the titration with Asp are shown in Fig. S67. $\uparrow$ The results are compatible with the formation of two complexes, CuAsp and CuAsp $\mathrm{P}_{2}$. The absorption is blue shifted upon complexation giving a maximum around $700 \mathrm{~nm}$ for the $1: 1$ complex and $637 \mathrm{~nm}$ for the $1: 2$ complex. The stability constants obtained by fitting the data to this equilibrium pattern are reported in Table 3 (entries 1-3).

Similar results were obtained regarding the $\mathrm{Cu}$ (II) complexation with Mal (Fig. S68 $\dagger$ ). In this case the $1: 1$ complex absorbs mainly in the 700-800 $\mathrm{nm}$ region whereas the $1: 2$ complex has a maximum around $694 \mathrm{~nm}$ (Table 3, entries 4-6). In both cases, the stability constants are high enough to allow the formation of the $1: 2$ complexes $\left(\mathrm{CuL}_{2}\right)$ under the conditions used for the UV-vis study $\left(\left[\mathrm{Cu}^{2+}\right] \approx 1 \times 10^{-3} \mathrm{M}\right.$; [dicarboxylate] up to $4 \times 10^{-3} \mathrm{M}$ ). Besides, the stability of the complexes formed by $\mathrm{Cu}(\mathrm{II})$ with Asp was seen to be slightly higher than those formed with Mal.

Following this, we determined the equilibrium constant for the formation of the CuL1 complex (entries 7-9 in Table 3). The titration revealed the formation of a transient complex with a $2: 1$ stoichiometry, $\mathrm{Cu}_{2} \mathbf{L} 1$. Finally the titrations of CuL1
Table 3 Stepwise and cumulative formation constants determined by UV-vis titrations in methanol at $298 \mathrm{~K}$. The standard deviations are reported in parentheses as uncertainties on the last significant figure

\begin{tabular}{|c|c|c|c|}
\hline Entry & Reaction $^{a}$ & $\log \beta$ & $\log K$ \\
\hline 1 & $\mathrm{Cu}+\mathrm{Asp} \rightarrow \mathrm{CuAsp}$ & $6.08(3)$ & \\
\hline 2 & $\mathrm{Cu}+2 \mathrm{Asp} \rightarrow \mathrm{CuAsp} p_{2}$ & $10.75(3)$ & \\
\hline 3 & CuAsp + Asp $\rightarrow \mathrm{CuAsp}_{2}$ & & 4.67 \\
\hline 4 & $\mathrm{Cu}+\mathrm{Mal} \rightarrow \mathrm{CuMal}$ & $5.77(4)$ & \\
\hline 5 & $\mathrm{Cu}+2 \mathrm{Mal} \rightarrow \mathrm{CuMal}_{2}$ & $10.08(4)$ & \\
\hline 6 & $\mathrm{CuMal}+\mathrm{Mal} \rightarrow \mathrm{CuMal}_{2}$ & & 4.31 \\
\hline 7 & $\mathrm{Cu}+\mathbf{L 1} \rightarrow \mathrm{CuL1}$ & $5.40(4)$ & \\
\hline 8 & $2 \mathrm{Cu}+\mathbf{L} \mathbf{1} \rightarrow \mathrm{Cu}_{2} \mathbf{L} \mathbf{1}$ & $9.25(4)$ & \\
\hline 9 & $\mathrm{Cu}+\mathrm{CuL1} \rightarrow \mathrm{Cu}_{2} \mathbf{L} \mathbf{1}$ & & 3.85 \\
\hline 10 & $\mathrm{Cu}+\mathbf{L} \mathbf{1}+\mathrm{Asp} \rightarrow \mathrm{CuL1Asp}$ & $9.90(1)$ & \\
\hline 11 & CuL1 + Asp $\rightarrow$ CuL1Asp & & 4.50 \\
\hline 12 & $\mathrm{Cu}+\mathbf{L 1}+\mathrm{Mal} \rightarrow \mathrm{CuL1Mal}$ & $11.01(3)$ & \\
\hline 13 & CuL1 + Mal $\rightarrow$ CuL1Mal & & 5.61 \\
\hline
\end{tabular}

vs. Mal and Asp were carried out, allowing the determination of the stability constants for the corresponding ternary complexes (entries 10 and 12 in Table 3). Interestingly, the ternary complex with Mal is one order of magnitude more stable than the one with Asp, which is evident when comparing the corresponding stepwise equilibrium constants (entries 11 and 13 in Table 3). Thus, the analysis of the data reported in Table 3 underscores the different behaviour of CuL1 in the presence of Mal and Asp anions. This difference is clearer by plotting the species distribution during the titration of the CuL1 complex with either Mal or Asp dicarboxylates (Fig. 7). In the case of Mal, the addition of one equivalent of dicarboxylate mainly led to the formation of the ternary species (CuL1Mal) while for Asp, a complex mixture was obtained, due to the efficient displacement of the $\mathrm{Cu}$ ion from $\mathrm{CuL1}$, produced by the Asp ligand.

Thus, as described in Fig. 7, CuL1 can form a ternary complex with both Mal and Asp, but while in the first case this complex is relatively stable, in the latter the equilibrium is shifted towards the formation of $\mathrm{CuAsp}_{2}$ and the free $\mathbf{L 1}$ ligand (Scheme 3). EPR spectra of CuL1 in the presence of a slight excess (ca. 2 equivalents) of Asp and Mal supported this
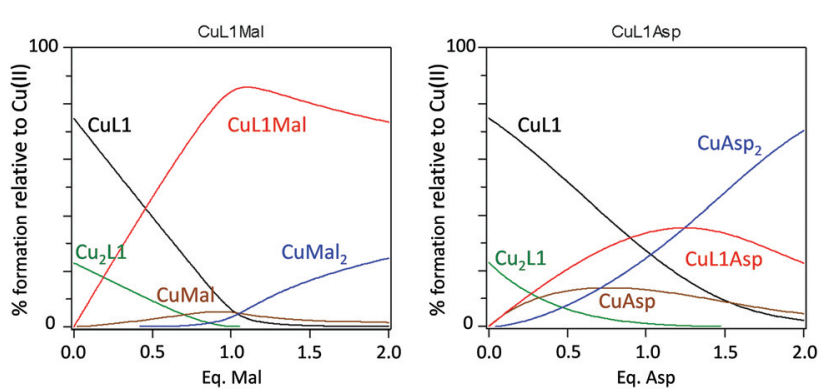

Fig. 7 Species distribution for the titration of the CuL1 complex with Mal (left) or Asp (right). The plot was generated using the stability constants reported in Table 3 and $[\mathrm{Cu}]=[\mathrm{L} 1]=1 \times 10^{-3} \mathrm{M}$. 


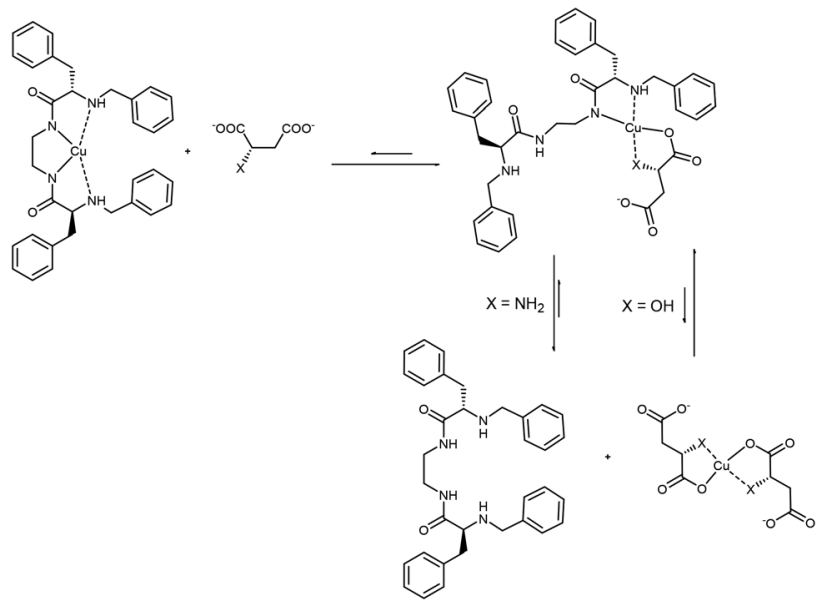

Scheme 3 Proposed model of interaction of CuL1 with malate $(X=$ $\mathrm{OH})$ and aspartate $\left(\mathrm{X}=\mathrm{NH}_{2}\right)$.

hypothesis, as they showed the formation, in both cases, of $\mathrm{Cu}$ (II) species with $\mathrm{CuN}_{2} \mathrm{O}_{2}$ coordination, and overall zero charge (Table 2, entries 1, 8, 9 and Fig. S26 †). In particular, the EPR spectrum of the CuL1/Asp system is very similar to that of $\mathrm{CuAsp}_{2}$ (obtained by mixing $\mathrm{CuSO}_{4}$ and Asp in methanol) (Fig. S30†) with close spectral parameters (entry 10, Table 2). In the case of Mal, the EPR spectrum (Fig. S31†) shows two components of different intensities, both assignable to $\mathrm{CuN}_{2} \mathrm{O}_{2}$ coordination. This may be due to two different dispositions of the Mal anion in the ternary complex; in fact, the carboxylate ligand can be in a cis or trans position relative to the amino ligand in the $\mathrm{Cu}$ complex. The structure proposed for the ternary supramolecular complex CuL1Mal also fits well the ATR-IR spectrum (Fig. S22†), which shows for the ternary complex a broad band with two major components: 1650 and $1593 \mathrm{~cm}^{-1}$, relative to free and metal-coordinated amides, respectively. The complexity of the equilibria prevented us to undertake the same detailed study for the dinuclear $\mathrm{Cu}_{2} \mathbf{L} 3$ complex. In particular, the stability constant of the macrocyclic $\mathrm{Cu}_{2} \mathbf{L} 3$ complex was too high to be accurately determined by UV-vis titrations in the required concentration range. However, the main difference between $\mathbf{C u L 1}$ and $\mathrm{Cu}_{2} \mathbf{L} \mathbf{3}$ seems to be the lower tendency of the macrocyclic ligand to transfer the metal to Asp anions, probably due to the higher stability of the $\mathrm{Cu}_{2} \mathbf{L} \mathbf{3}$ complex due to the macrocyclic effect.

\section{Experimental}

\section{Synthesis of the ligands}

Primary diamines $\mathbf{1}$ and $\mathbf{2}$ were prepared as already described. ${ }^{17}$

L1: To a solution of $1(360 \mathrm{mg}, 1.01 \mathrm{mmol})$ in methanol $(15 \mathrm{ml})$ was added benzaldehyde $(454 \mu \mathrm{l}, 4.46 \mathrm{mmol})$ and the resulting solution was stirred at room temperature for 6 hours. Sodium borohydride ( $470 \mathrm{mg}, 12.2 \mathrm{mmol}$ ) was added in an ice bath and the reaction mixture was stirred at room temperature for16 hours. Aqueous $4 \mathrm{M} \mathrm{HCl}$ was added, and a white solid formed. After 1 hour the solvents were evaporated at reduced pressure, affording a solid that was suspended in aqueous $4 \mathrm{M}$ $\mathrm{NaOH}$. The product was extracted twice with DCM and once with AcOEt. Organic layers were combined, dried over $\mathrm{MgSO}_{4}$ and concentrated at reduced pressure. The resulting thick oil was suspended in diethyl ether, triturated, filtered and washed with additional diethyl ether, affording $\mathbf{L 1}$ as a white solid (440 mg, $0.82 \mathrm{mmol}, 81 \%$ yield).

${ }^{1} \mathrm{H}-\mathrm{NMR}\left(400 \mathrm{MHz}, \mathrm{CDCl}_{3}\right) \delta 7.29$ (bs, $\left.2 \mathrm{H}\right), 7.26-7.15$ (m, 12H), 7.12-7.09 (m, 4H), $7.05(\mathrm{dd}, J=7.5,1.9 \mathrm{~Hz}, 4 \mathrm{H}), 3.66$ (d, $J=13.4 \mathrm{~Hz}, 2 \mathrm{H}), 3.48(\mathrm{~d}, J=13.4 \mathrm{~Hz}, 2 \mathrm{H}), 3.37-3.21(\mathrm{~m}$, $4 \mathrm{H}), 3.29(\mathrm{dd}, J=9.1,4.8 \mathrm{~Hz}, 2 \mathrm{H}), 3.13(\mathrm{dd}, J=13.8,4.7 \mathrm{~Hz}$, $2 \mathrm{H}), 2.71(\mathrm{dd}, J=13.8,9.1 \mathrm{~Hz}, 2 \mathrm{H}), 1.65$ (bs, $2 \mathrm{H}) .{ }^{13} \mathrm{C}-\mathrm{NMR}$ $\left(101 \mathrm{MHz}, \mathrm{CDCl}_{3}\right) \delta 174.4,139.2,137.5,129.3,128.8,128.6$, 128.0, 127.3, 127.0, 63.2, 52.7, 39.5, 39.3. HRMS (ESI-TOF) $\mathrm{m} / \mathrm{z}$ $[\mathbf{L 1}-\mathrm{H}]^{-}$Calcd for $\left(\mathrm{C}_{34} \mathrm{H}_{37} \mathrm{~N}_{4} \mathrm{O}_{2}\right)$ 535.3073, found 535.3080. IR $\left(\mathrm{KBr}, \nu \mathrm{cm}^{-1}\right): 3345,3282,1652,1522,745,697$.

L2: Obtained following the same procedure described for L1, using 2 (400 $\mathrm{mg}, 0.82 \mathrm{mmol}$ ) as the starting material. L2 was obtained as a waxy solid ( $240 \mathrm{mg}, 0.82 \mathrm{mmol}, 44 \%$ yield). ${ }^{1} \mathrm{H}-\mathrm{NMR}\left(400 \mathrm{MHz}, \mathrm{CDCl}_{3}\right) \delta 7.52(\mathrm{t}, J=6.4 \mathrm{~Hz}, 2 \mathrm{H}), 7.35-7.18$ $(\mathrm{m}, 12 \mathrm{H}), 7.14(\mathrm{~d}, J=6.6 \mathrm{~Hz}, 4 \mathrm{H}), 7.07(\mathrm{~d}, J=7.4 \mathrm{~Hz}, 4 \mathrm{H}), 3.70$ $(\mathrm{d}, J=13.4 \mathrm{~Hz}, 2 \mathrm{H}), 3.53(\mathrm{~d}, J=13.4 \mathrm{~Hz}, 2 \mathrm{H}), 3.36(\mathrm{dd}, J=9.3$, $4.4 \mathrm{~Hz}, 2 \mathrm{H}), 3.20-3.09(\mathrm{~m}, 6 \mathrm{H}), 2.73(\mathrm{dd}, J=13.8,9.3 \mathrm{~Hz}, 2 \mathrm{H})$, 1.75 (bs, 2H), 1.54 (p, $J=6.4 \mathrm{~Hz}, 2 \mathrm{H}) .{ }^{13} \mathrm{C}-\mathrm{NMR}(101 \mathrm{MHz}$, $\left.\mathrm{CDCl}_{3}\right) \delta 174.0,139.2,137.4,129.1,128.7,128.5,128.0,127.1$, 126.8, 63.2, 52.6, 39.4, 35.6, 30.0. HRMS (ESI-TOF) $\mathrm{m} / \mathrm{z}$ $[\mathbf{L 2}-\mathrm{H}]^{-}$Calcd for $\left(\mathrm{C}_{35} \mathrm{H}_{39} \mathrm{~N}_{4} \mathrm{O}_{2}\right)$ 547.3076, found 547.3073. IR $\left(\mathrm{KBr}, \nu \mathrm{cm}^{-1}\right): 3415,3229,1638,1617,1398$.

L3 and L4 were prepared as already described. ${ }^{18}$ L3: IR $\left(\mathrm{KBr}, \nu \mathrm{cm}^{-1}\right): 3415,1653,1521,702$. L4: IR $\left(\mathrm{KBr}, \nu \mathrm{cm}^{-1}\right)$ : 3417, 3232, 1643, 1520, 1397, 699.

\section{Synthesis of the $\mathrm{Cu}$ (II) complexes}

CuL1: To a solution of L1 (105 mg, $0.197 \mathrm{mmol})$ in $\mathrm{MeOH}$ $(20 \mathrm{~mL})$ were added $\mathrm{CuSO}_{4} \cdot 5 \mathrm{H}_{2} \mathrm{O}(50 \mathrm{mg}, 0.200 \mathrm{mmol})$ and $\mathrm{NaOH}(16 \mathrm{mg}, 0.40 \mathrm{mmol})$. A colour change from blue to purple was observed. The reaction mixture was stirred for 30 minutes at room temperature and then centrifuged for 10 minutes. The white solid was discarded while the purple solution was concentrated at reduced pressure. CuL1 was obtained as a purple solid (94 mg, $0.157 \mathrm{mmol}, 80 \%$ yield). UV-vis $\left(1 \times 10^{-3} \mathrm{M}, \mathrm{MeOH}\right) \lambda_{\max }=510 \mathrm{~nm} ; \varepsilon=226 \mathrm{M}^{-1}$ $\mathrm{cm}^{-1}$. HRMS (ESI-TOF) $\mathrm{m} / \mathrm{z}[\mathrm{CuL1}+\mathrm{Cl}]^{-}$Calcd for $\left(\mathrm{C}_{34} \mathrm{H}_{36}{ }^{35} \mathrm{Cl}^{63} \mathrm{CuN}_{4} \mathrm{O}_{2}\right)$ 630.1823, found 630.1899; [CuL1 + $\mathrm{HCOO}]^{-}$Calcd for $\left(\mathrm{C}_{35} \mathrm{H}_{37}{ }^{63} \mathrm{CuN}_{4} \mathrm{O}_{4}\right)$ 640.2111, found 640.2189. IR (KBr, $\left.\nu \mathrm{cm}^{-1}\right): 3406,1598,1454,751,700$. Elemental analysis: found: C: $64.75 \%, \mathrm{H}: 5.93 \%$; N: $8.75 \%$; calculated for CuL1 + $2 \mathrm{H}_{2} \mathrm{O}$; C: $64.59 \%$, H: 6.38\%, N: 8.86\%.

CuL2: Prepared following the same procedure described for CuL1. CuL2 was obtained as a pink solid. $76 \%$ yield. UV-vis $\left(2.4 \times 10^{-3} \mathrm{M}, \mathrm{MeOH}\right) \lambda_{\max }=498 \mathrm{~nm} ; \varepsilon=94 \mathrm{M}^{-1} \mathrm{~cm}^{-1}$. HRMS (ESI-TOF) $\mathrm{m} / z[\mathrm{CuL} 2+\mathrm{Cl}]^{-}$Calcd for $\left(\mathrm{C}_{35} \mathrm{H}_{38}{ }^{35} \mathrm{Cl}^{63} \mathrm{CuN}_{4} \mathrm{O}_{2}\right)$ 644.1979, found 644.2072; [CuL2 $+\mathrm{HCOO}^{-}$Calcd for 
$\left(\mathrm{C}_{36} \mathrm{H}_{39}{ }^{63} \mathrm{CuN}_{4} \mathrm{O}_{4}\right)$ 654.2267, found 654.2340. IR ( $\left.\mathrm{KBr}, \nu \mathrm{cm}^{-1}\right)$ : 3405, 3229, 1576, 1398. Elemental analysis: found: C: $63.66 \%$, $\mathrm{H}: 6.35 \%$; N: 8.43\%; calculated for $\mathrm{CuL2}+3 \mathrm{H}_{2} \mathrm{O}$; C: $63.28 \%$, H: $6.68 \%$, N: $8.43 \%$.

$\mathrm{Cu}_{2} \mathbf{L} 3$ : To a solution of $\mathbf{L 3}(215 \mathrm{mg}, 0.228 \mathrm{mmol})$ in $\mathrm{MeOH}$ $(25 \mathrm{~mL})$ were added $\mathrm{CuSO}_{4} \cdot 5 \mathrm{H}_{2} \mathrm{O}(115 \mathrm{mg}, 0.46 \mathrm{mmol})$ and $\mathrm{NaOH}$ (37 mg, $0.92 \mathrm{mmol}$ ). A colour change from blue to purple was observed. The reaction mixture was stirred for 30 minutes at room temperature and then centrifuged for 10 minutes. The white solid was discarded while the purple solution was concentrated at reduced pressure. $\mathrm{Cu}_{2} \mathbf{L} \mathbf{3}$ was obtained as a purple solid (175 $\mathrm{mg}, 0.164 \mathrm{mmol}, 72 \%$ yield). UV-vis $\left(7 \times 10^{-4} \mathrm{M}, \mathrm{MeOH}\right) \lambda_{\max }=526 \mathrm{~nm} ; \varepsilon=365 \mathrm{M}^{-1} \mathrm{~cm}^{-1}$. HRMS (ESI-TOF) $\mathrm{m} / z \quad\left[\mathrm{Cu}_{2} \mathbf{L} 3+\mathrm{HCOO}^{-}\right.$Calcd for $\left(\mathrm{C}_{57} \mathrm{H}_{61}{ }^{63} \mathrm{Cu}_{2} \mathrm{~N}_{8} \mathrm{O}_{6}\right)$ 1081.3304, found 1081.3602. IR ( $\mathrm{KBr}, \nu$ $\mathrm{cm}^{-1}$ ): 3404, 1599, 702. Elemental analysis: found: C: $64.15 \%$, $\mathrm{H}: 6.21 \%$; N: 10.43\%; calculated for: $\mathrm{Cu}_{2} \mathbf{L} 3+1 \mathrm{H}_{2} \mathrm{O}$; C: $63.80 \%$, H: $5.93 \%, \mathrm{~N}: 10.63 \%$.

$\mathrm{Cu}_{2} \mathbf{L} 4$ : Prepared following the same procedure described for $\mathrm{Cu}_{2} \mathbf{L} 3 . \mathrm{Cu}_{2} \mathbf{L} 4$ was obtained as a pink solid. $81 \%$ yield. UVvis $\left(5 \times 10^{-4} \mathrm{M}, \mathrm{MeOH}\right) \lambda_{\max }=519 \mathrm{~nm} ; \varepsilon=319 \mathrm{M}^{-1} \mathrm{~cm}^{-1}$. HRMS (ESI-TOF) $\mathrm{m} / \mathrm{z} \quad\left[\mathrm{Cu}_{2} \mathbf{L 4}+\mathrm{HCOO}^{-}\right.$Calcd for $\left(\mathrm{C}_{57} \mathrm{H}_{61}{ }^{63} \mathrm{Cu}_{2} \mathrm{~N}_{8} \mathrm{O}_{6}\right)$ 1081.3304, found 1081.3629. IR ( $\mathrm{KBr}, \nu$ $\mathrm{cm}^{-1}$ ): 3414, 3229, 1614, 1397. Elemental analysis: found: $\mathrm{C}$ : 63.75\%, H: 5.95\%; N: 10.38\%; calculated for $\mathrm{Cu}_{2} \mathbf{L 4}+1 \mathrm{H}_{2} \mathrm{O}$; C: $63.80 \%, \mathrm{H}: 5.93 \%$, N: $10.63 \%$.

\section{EPR experiments}

EPR spectra of $\mathrm{Cu}$ (II) complexes in methanol at $103 \mathrm{~K}$ were recorded on a Bruker EMX-Plus 10/12 Bruker BioSpin spectrometer with an X-band microwave bridge EMX Premium X, a 10"ERO73 magnet and a power supply of $12 \mathrm{~kW}$ (ERO83). The temperature was controlled by a Bruker ER 4111 VT temperature control system. Spectrometer parameters for acquiring spectra were: magnetic field, $3300 \mathrm{G}$ with a sweep width of $2000 \mathrm{G}$. A $15.170 \mathrm{~mW}$ microwave power at a frequency of 9.442 $\mathrm{GHz}$ was used with a modulation amplitude of $1.60 \mathrm{G}$ and a frequency of $100 \mathrm{kHz}$. The EPR spectra were simulated with software from Bruker WIN-EPR system (v 2.22 Rev. 12) and WIN-EPR SimFonia (v 1.26 beta).

\section{UV-vis titrations}

All the titrations were carried out in methanol. UV-vis spectra were recorded on a SpectraMax M5 spectrophotometer. The association constants were calculated using the HypSpec 1.1.33 software for Windows. ${ }^{32}$ Species distributions of Fig. 7 were made with the HySS software (http://www.hyperquad.co. uk/hyss.htm).

Formation of $\mathrm{CuAsp}_{2}$ and $\mathrm{CuMal}_{2}$ : a solution of $1.4 \times 10^{-3}$ $\mathrm{M} \mathrm{CuSO}_{4} \cdot 5 \mathrm{H}_{2} \mathrm{O}$ was titrated respectively with $1.4 \times 10^{-2} \mathrm{M}$ $(\mathrm{TBA})_{2}$-L-aspartate and $1.4 \times 10^{-2} \mathrm{M}(\mathrm{TBA})_{2}$-L-malate (from 0 to 3.0 equivalents). The absorption variations from 500 to $800 \mathrm{~nm}$ were fitted to $1: 1$ and $1: 2$ models.

Formation of CuL1: a solution of $\mathrm{CuSO}_{4} 7 \times 10^{-4} \mathrm{M}$ was titrated in batch with a solution of $\mathbf{L 1} 7.0 \times 10^{-3} \mathrm{M}$ containing 2.2 equivalents of TBAOH. The next procedure was followed: several samples containing $1 \mathrm{~mL}$ of the $\mathrm{Cu}$ (II) solution and increasing amounts of the $\mathbf{L} \mathbf{1}$ solution (from 0 to 3.0 equivalents) were prepared and left to equilibrate for 24 hours prior to the measurement in the spectrophotometer.

CuL1 vs. dicarboxylates: a solution of $1 \times 10^{-3} \mathrm{M}$ CuL1 was titrated with $2.0 \times 10^{-2} \mathrm{M}(\mathrm{TBA})_{2}$-dicarboxylate (from 0 to 3.0 equivalents). In the case of malate and aspartate, the association constants were calculated fitting the absorption variations from 450 to $750 \mathrm{~nm}$. For these fittings, the corresponding stability constants for $\mathrm{CuL1}$ and the Cu-dicarboxylate complexes were introduced as constant fixed values.

$\mathrm{Cu}_{2} \mathbf{L} 3$ and $\mathrm{Cu}_{2} \mathbf{L} \mathbf{4}$ vs. dicarboxylates: a solution of $7 \times 10^{-4}$ $\mathbf{M ~ C u}{ }_{2} \mathbf{L} 3$ (or $\left.\mathrm{Cu}_{2} \mathbf{L} 4\right)$ was titrated with $1.4 \times 10^{-3} \mathrm{M}(\mathrm{TBA})_{2^{-}}$ dicarboxylate (from 0 to 4.0 equivalents).

\section{Crystal structure determination}

Data for all structures were collected on a STOE IPDS II twocircle diffractometer with a Genix Microfocus tube with mirror optics using $\operatorname{MoK}_{\alpha}$ radiation $(\lambda=0.71073 \AA)$ and were scaled using the frame scaling procedure in the X-AREA program system. ${ }^{33}$

The structures were solved by direct methods using the program SHELXS and refined against $F^{2}$ with full-matrix leastsquares techniques using the program SHELXL-97. ${ }^{34}$

All $\mathrm{H}$ atoms in $\mathbf{L} 1$ were refined using a riding model. Due to the absence of anomalous scatterers, the absolute configuration could not be determined.

The $\mathrm{H}$ atoms bonded to $\mathrm{N}$ and $\mathrm{O}$ in $\mathrm{CuL} 2$ were freely refined. The absolute configuration was determined by refining the Flack- $x$-parameter, $x=-0.025(13)$ (Table 4).

CCDC 1059976 (L1) and CCDC 1059975 (CuL2) contain the supplementary crystallographic data for this paper.

Table 4 Crystal data and structure refinement for L1 and CuL2

\begin{tabular}{|c|c|c|}
\hline Compounds & L1 & CuL2 \\
\hline Empirical formula & $\mathrm{C}_{34} \mathrm{H}_{38} \mathrm{~N}_{4} \mathrm{O}_{2}$ & $\mathrm{C}_{36} \mathrm{H}_{42} \mathrm{CuN}_{4} \mathrm{O}_{3}$ \\
\hline Form. weight $\left[\mathrm{g} \mathrm{cm}^{-3}\right]$ & 534.68 & 642.27 \\
\hline Crystal system & Triclinic & Orthorhombic \\
\hline Space group & $P 1$ (no. 1) & $P 2_{1} 2_{1} 2_{1}$ (no. 19) \\
\hline$a[\AA]$ & $9.631(3)$ & $10.0943(8)$ \\
\hline$b[\AA]$ & $10.027(3)$ & $15.9068(10)$ \\
\hline$c[\AA]$ & $15.551(4)$ & $19.5472(13)$ \\
\hline$\alpha[0]$ & $86.83(2)$ & 90 \\
\hline$\beta\left[^{\circ}\right]$ & $87.67(2)$ & 90 \\
\hline$\gamma[0]$ & $78.27(2)$ & 90 \\
\hline Volume $\left[\AA^{3}\right]$ & $1467.5(7)$ & $3138.7(4)$ \\
\hline Absorption coeff. & 0.076 & 0.739 \\
\hline Reflections collected & 11889 & 13262 \\
\hline Unique reflections & 8265 & 5861 \\
\hline$R$ (int) & 0.1832 & 0.0591 \\
\hline Data/restraints/parm. & $8265 / 3 / 721$ & $5861 / 0 / 410$ \\
\hline$R_{1}[I>2 \sigma(I)]$ & 0.148 & 0.0365 \\
\hline $\mathrm{w} R_{2}$ [all data] & 0.418 & 0.0821 \\
\hline GooF & 1.064 & 1.002 \\
\hline Diff. peak $\left[\mathrm{e} \AA^{-1}\right]$ & 0.544 & 0.315 \\
\hline Diff. hole $\left[\mathrm{e} \AA^{-1}\right]$ & -0.661 & -0.451 \\
\hline
\end{tabular}




\section{Conclusions}

The present study reports the synthesis and the characterization of mononuclear $\mathrm{Cu}$ (II) complexes with bis(amino amide) ligands (L1 and L2) and dinuclear Cu(II) complexes with tetra(amino amide) ligands (L3 and L4). The metal ion always displays the square planar coordination geometry, being connected to four nitrogen atoms (two amines and two deprotonated amides).

The complexes interact with hydroxy- and amino-dicarboxylate substrates, and this event provokes a strong change in the visible absorption spectra. In particular, the interaction with two biologically important dicarboxylates possessing very similar structures (malate and aspartate) has a completely different outcome. In the case of malate, a ternary complex [ligand...metal...dicarboxylate] is formed almost quantitatively; while in the case of aspartate, the anion is able to displace $\mathrm{Cu}(\mathrm{II})$ from the ligand to form, mainly, the $\mathrm{Cu}(\mathrm{Asp})_{2}$ complex. These complexes are model compounds that mimic the ligand exchange observed in natural systems and especially the function of metal ionophores. In fact, ionophores are specific ligands that bind a metal cation, transport it across a cellular membrane, and then release it in response to different stimuli (for example lower $\mathrm{pH}$ or presence of competitive ligands).

We are currently exploiting the modularity of the structure of the pseudopeptidic ligands, that allow changes in the spacer, the amino acid residue and the amine substituent, in order to improve the solubility of the $\mathrm{Cu}$ (II) complexes in water and tune their stability.

\section{Acknowledgements}

This work was supported by the Spanish Ministry of Economy and Competitiveness (MINECO, CTQ2012-38543-C03-03 and CTQ2012-36074) and Generalitat de Catalunya (2014 SGR 231). This research was also supported by a Marie Curie Intra European Fellowship within the 7th European Community Framework Programme (R. G.). E. F. thanks CSIC for the concession of a $J A E-D O c$ grant, a program co-funded by the European Social Fund. We thank Daniel Heras, Mari Carmen Alcalá, Miquel Sintes and Sandra Bassas for performing some experiments.

\section{Notes and references}

1 (a) M. C. Linder, Biochemistry of Copper, Springer, US, 1991; (b) E. D. Harris, Annu. Rev. Nutr., 2000, 20, 291; (c) H.-B. Kraatz and N. Metzler-Nolte, Concepts and models in bioinorganic chemistry, Wiley-VCH Weinheim, Germany, 2006; (d) I. Bertini, Biological inorganic chemistry: structure and reactivity, University Science Books, 2007.

2 (a) A. C. Rosenzweig and T. V. O'Halloran, Curr. Opin. Chem. Biol., 2000, 4, 140; (b) E. I. Solomon, P. Chen,
M. Metz, S.-K. Lee and A. E. Palmer, Angew. Chem., Int. Ed., 2001, 40, 4570; (c) G. Henkel and B. Krebs, Chem. Rev., 2004, 104, 801; (d) E. I. Solomon, R. K. Szilagyi, S. DeBeer George and L. Basumallick, Chem. Rev., 2004, 104, 419; (e) P. C. Ford, B. O. Fernandez and M. D. Lim, Chem. Rev., 2005, 105, 2439; $(f)$ M. L. Zastrow and V. L. Pecoraro, Coord. Chem. Rev., 2013, 257, 2565.

3 (a) R. H. Holm, P. Kennepohl and E. I. Solomon, Chem. Rev., 1996, 96, 2239; (b) J. T. Rubino and K. J. Franz, J. Inorg. Biochem., 2012, 107, 129; (c) E. I. Solomon, D. E. Heppner, E. M. Johnston, J. W. Ginsbach, J. Cirera, M. Qayyum, M. T. Kieber-Emmons, C. H. Kjaergaard, R. G. Hadt and L. Tian, Chem. Rev., 2014, 114, 3659.

4 (a) A. L. van den Brenk, D. P. Fairlie, G. R. Hanson, L. R. Gahan, C. J. Hawkins and A. Jones, Inorg. Chem., 1994, 33, 2280; (b) P. V. Bernhardt, P. Comba, D. P. Fairlie, L. R. Gahan, G. R. Hanson and L. Lötzbeyer, Chem. - Eur. J., 2002, 8, 1527; (c) P. Comba, L. R. Gahan, G. Haberhauer, G. R. Hanson, C. J. Noble, B. Seibold and A. L. van den Brenk, Chem. - Eur. J., 2008, 14, 4393; (d) P. Comba, N. Dovalil, L. R. Gahan, G. Haberhauer, G. R. Hanson, C. J. Noble, B. Seibold and P. Vadivelu, Chem. - Eur. J., 2012, 18, 2578; (e) P. Comba, N. Dovalil, L. R. Gahan, G. R. Hanson and M. Westphal, Dalton Trans., 2014, 43, 1935.

5 (a) M. Remelli, M. Peana, S. Medici, L. G. Delogu and M. A. Zoroddu, Dalton Trans., 2013, 42, 5964; (b) S. C. Drew, Chem. - Eur. J., 2015, 21, 7111.

6 (a) J. L. Hickey, P. J. Crouch, S. Mey, A. Caragounis, J. M. White, A. R. White and P. S. Donnelly, Dalton Trans., 2011, 40, 1338; (b) S. Tardito, I. Bassanetti, C. Bignardi, L. Elviri, M. Tegoni, C. Mucchino, O. Bussolati, R. FranchiGazzola and L. Marchiò, J. Am. Chem. Soc., 2011, 133, 6235; (c) V. Oliveri, M. Viale, G. Caron, C. Aiello, R. Gangemi and G. Vecchio, Dalton Trans., 2013, 42, 2023.

7 (a) R. Österberg, Coord. Chem. Rev., 1974, 12, 309; (b) V. Lillo and J. R. Galán-Mascarós, Dalton Trans., 2014, 43, 9821.

8 (a) B. Gyurcsik, T. Gajda, L. Nagy and K. Burger, J. Chem. Soc., Dalton Trans., 1992, 2787; (b) T. Gajda, B. Henry, A. Aubry and J.-J. Delpuech, Inorg. Chem., 1996, 35, 586; (c) H. Kurosaki, R. K. Sharma, S. Aoki, T. Inoue, Y. Okamoto, Y. Sugiura, M. Doi, T. Ishida, M. Otsuka and M. Goto, J. Chem. Soc., Dalton Trans., 2001, 441; (d) H. B. Albada, F. Soulimani, B. M. Weckhuysen and R. M. J. Liskamp, Chem. Commun., 2007, 4895; (e) S. Bhattacharyya, A. Sarkar, S. K. Dey, G. P. Jose, A. Mukherjee and T. K. Sengupta, Dalton Trans., 2013, 42, 11709; $(f)$ A.-S. Felten, N. Pellegrini-Moïse, K. Selmeczi, B. Henry and Y. Chapleur, Eur. J. Org. Chem., 2013, 5645; (g) S. Zhu, Z. Qiu, T. Ni, X. Zhao, S. Yan, F. Xing, Y. Zhao, Y. Bai and M. Li, Dalton Trans., 2013, 42, 10898.

9 S. V. Luis and I. Alfonso, Acc. Chem. Res., 2014, 47, 112.

10 (a) R. Marchelli, A. Dossena, G. Casnati, G. G. Fava and M. F. Belicchi, J. Chem. Soc., Chem. Commun., 1985, 1672; (b) T. R. Wagler, Y. Fang and C. J. Burrows, J. Org. Chem., 
1989, 54, 1584; (c) B. Dangel, M. Clarke, J. Haley, D. Sames and R. Polt, J. Am. Chem. Soc., 1997, 119, 10865; (d) C. L. Weeks, P. Turner, R. R. Fenton and P. A. Lay, J. Chem. Soc., Dalton Trans., 2002, 931; (e) M. I. Burguete, F. Galindo, S. V. Luis and L. Vigara, Dalton Trans., 2007, 4027.

11 F. Galindo, M. I. Burguete, L. Vigara, S. V. Luis, N. Kabir, J. Gavrilovic and D. A. Russell, Angew. Chem., Int. Ed., 2005, 44, 6504 .

12 (a) I. Alfonso, M. Bolte, M. Bru, M. I. Burguete, S. V. Luis and C. Vicent, Org. Biomol. Chem., 2010, 8, 1329; (b) E. Faggi, A. Moure, M. Bolte, C. Vicent, S. V. Luis and I. Alfonso, J. Org. Chem., 2014, 79, 4590.

13 S. Blasco, M. I. Burguete, M. P. Clares, E. García-España, J. Escorihuela and S. V. Luis, Inorg. Chem., 2010, 49, 7841.

14 I. Marti, A. Ferrer, J. Escorihuela, M. I. Burguete and S. V. Luis, Dalton Trans., 2012, 41, 6764.

15 I. Alfonso, I. Burguete, S. V. Luis, J. F. Miravet, P. Seliger and E. Tomal, Org. Biomol. Chem., 2006, 4, 853.

16 (a) J. Berg, J. Tymoczko and L. Stryer, Biochemistry, Freeman, 5th edn, 2002; (b) D. L. Nelson, A. L. Lehninger and M. M. Cox, Lehninger principles of biochemistry, Macmillan, 2008.

17 J. Becerril, M. Bolte, M. I. Burguete, F. Galindo, E. GarcíaEspaña, S. V. Luis and J. F. Miravet, J. Am. Chem. Soc., 2003, 125, 6677.

18 I. Alfonso, M. Bolte, M. Bru, M. I. Burguete, S. V. Luis and J. Rubio, J. Am. Chem. Soc., 2008, 130, 6137.

19 J. Peisach and W. E. Blumberg, Arch. Biochem. Biophys., 1974, 165, 691.

20 U. Sakaguchi and A. W. Addison, J. Chem. Soc., Dalton Trans., 1979, 600.

21 E. Mills and L. A. O’Neill, Trends Cell Biol., 2014, 24, 313.

22 M. J. West-Eberhard, J. A. C. Smith and K. Winter, Science, 2011, 332, 311.

23 B. J. Miflin and P. J. Lea, Annu. Rev. Plant Physiol., 1977, 28, 299.

24 A. Cavallero, A. Marte and E. Fedele, J. Neurochem., 2009, 110, 924.
25 D. Curiel, M. Más-Montoya and G. Sánchez, Coord. Chem. Rev., 2015, 284, 19.

26 L. Fabbrizzi and A. Poggi, Chem. Soc. Rev., 2013, 42, 1681.

27 (a) Q. Lu, J. J. Reibenspies, A. E. Martell and R. J. Motekaitis, Inorg. Chem., 1996, 35, 2630; (b) C. Bazzicalupi, A. Bencini, A. Bianchi, V. Fusi, E. GarciaEspaña, C. Giorgi, J. M. Llinares, J. A. Ramirez and B. Valtancoli, Inorg. Chem., 1999, 38, 620; (c) S. Carvalho, C. Cruz, R. Delgado, M. G. B. Drew and V. Felix, Dalton Trans., 2003, 4261; (d) F. Li, R. Delgado and V. Félix, Eur. J. Inorg. Chem., 2005, 4550; (e) M. Boiocchi, M. Bonizzoni, A. Moletti, D. Pasini and A. Taglietti, New J. Chem., 2007, 31, 352; (f) S. 1. Carvalho, R. Delgado, M. G. B. Drew and V. Félix, Dalton Trans., 2007, 2431; (g) L. Tang, J. Park, H.-J. Kim, Y. Kim, S. J. Kim, J. Chin and K. M. Kim, J. Am. Chem. Soc., 2008, 130, 12606; (h) F. Li, S. Carvalho, R. Delgado, M. G. Drew and V. Félix, Dalton Trans., 2010, 39, 9579; (i) M. Hu and G. Feng, Chem. Commun., 2012, 48, 6951.

28 (a) M. Boiocchi, M. Bonizzoni, L. Fabbrizzi, G. Piovani and A. Taglietti, Angew. Chem., Int. Ed., 2004, 43, 3847; (b) G. Y. Xie, L. Jiang and T. B. Lu, Dalton Trans., 2013, 42, 14092; (c) P. Mateus, R. Delgado, V. Andre and M. T. Duarte, Inorg. Chem., 2015, 54, 229.

29 T. Gärtner and R. M. Gschwind, in PATAI'S Chemistry of Functional Groups, John Wiley \& Sons, Ltd, 2009.

30 (a) L.-J. Tang and M.-H. Liu, Bull. Korean Chem. Soc., 2010, 31, 3159; (b) P. Mateus, R. Delgado, P. Brandao and V. Felix, Chem. - Eur. J., 2011, 17, 702.

31 (a) K. S. Rajan and A. E. Martell, J. Inorg. Nucl. Chem., 1967, 29, 463; (b) H. Sigel, Metal Ions in Biological Systems: Amino Acids and Derivatives as Ambivalent Ligands, Marcel Dekker, 1979; (c) A. Manceau and A. Matynia, Geochim. Cosmochim. Acta, 2010, 74, 2556.

32 P. Gans, A. Sabatini and A. Vacca, Talanta, 1996, 1739.

33 S. Cie, X-AREA., Diffractometer control program system, Stoe \& Cie, Darmstadt, Germany, 2002.

34 G. Sheldrick, Acta Crystallogr., Sect. A: Fundam. Crystallogr., 2008, 64, 112. 